\title{
Rhodothermus profundi sp. nov., a thermophilic bacterium isolated from a deep-sea hydrothermal vent in the Pacific Ocean
}

Correspondence

Viggó Thór Marteinsson viggo.th.marteinsson@matis.is

\author{
Viggó Thór Marteinsson, ${ }^{1}$ Snaedis H. Bjornsdottir, ${ }^{1,2}$ Nadège Bienvenu, ${ }^{3}$ \\ Jakob K. Kristjansson ${ }^{4}$ and Jean-Louis Birrien ${ }^{3}$ \\ ${ }^{1}$ Matis Vinlandsleid 12, IS-113, Reykjavik, Iceland \\ ${ }^{2}$ Institute of Biology, University of Iceland, Sturlugata 7, IS-101, Reykjavik, Iceland \\ ${ }^{3}$ UMR 6197, Centre National de la Recherche Scientifique, Université de Bretagne Occidentale, \\ Ifremer, IUEM, BP70, 29282 Plouzané, France \\ ${ }^{4}$ Arkea Technology Park, Reykir, PO Box 200, IS-810 Hveragerdi, Iceland
}

At the time of writing, the assignment of the family 'Rhodothermaceae', phylum 'Bacteroidetes', is uncertain (Ludwig et al. 2008). The family contains two genera, Rhodothermus and Salinibacter. The former comprises a single species, Rhodothermus marinus. Since $R$. marinus DSM $4252^{\mathrm{T}}$ was first isolated from a shallow submarine hot spring in Iceland, many additional strains have been reported from marine geothermal sites around the world (Alfredsson et al., 1988; Bjornsdottir et al., 2006). Although originating from distantly located sites, $R$. marinus strains have been shown to be closely related on the basis of highly similar 16S rRNA gene sequences and DNA-DNA reassociation values of $68-96 \%$ (Moreira et al., 1996; Petursdottir et al., 2000; Silva et al., 2000). R. marinus strains are also very similar in their phenotypic characters.

Abbreviation: AFLP, amplified-fragment length polymorphism.

The GenBank/EMBL/DDBJ accession number for the 16S rRNA gene sequence of strain PRI $2902^{\top}$ is FJ624399.

A scanning electron micrograph of strain PRI $2902^{\top}$ is available with the online version of this paper.
Most are orange-reddish-pigmented, although colourless strains have been isolated (Petursdottir et al., 2000). R. marinus is non-spore-forming, heterotrophic, slightly halophilic, thermophilic and obligately aerobic (Alfredsson et al., 1988). Therefore, its growth in marine hot springs is confined to aerobic zones of suitable temperatures. It has been shown that aerobic heterotrophic bacteria, for example of the genera Thermus and Bacillus, are present in deep-sea hydrothermal vent environments (Marteinsson et al., 1995, 1996, 1999). Thus, we investigated whether the distribution of Rhodothermus encompassed such environments. This paper reports the isolation and characterization of thermophilic bacteria isolated from a deep-sea hydrothermal vent at the East-Pacific Rise at $13^{\circ} \mathrm{N}$ $\left(12.449844^{\circ} \mathrm{N} 103.56812^{\circ} \mathrm{W}\right)$ and assigns them to a novel species within the genus Rhodothermus.

Samples were collected during the French oceanographic cruise AMISTAD in June 1999. Chimney rocks, hot fluids and invertebrates were collected by the man-operated submersible Nautile and brought to the surface in an insulated box. Samples were immediately processed for 
enrichment aboard the ship and for transportation to the laboratory. Various media were used for aerobic enrichments at $65{ }^{\circ} \mathrm{C}$ and some growth was observed after 130 days of incubation. The novel isolates were obtained from an active chimney rock sample collected at a depth of $2634 \mathrm{~m}$. Rock pieces and sterile seawater were mixed together and kept at $4{ }^{\circ} \mathrm{C}$ until processing 2 weeks later in the laboratory. The mixture was inoculated into medium 160 (Degryse et al., 1978) containing $1 \% \mathrm{NaCl}$ and $2.5 \mathrm{~g} \mathrm{l}^{-1}$ each of tryptone and yeast extract (designated 160-1). The sample was serially diluted in $25 \mathrm{ml}$ culture tubes and incubated aerobically at $65{ }^{\circ} \mathrm{C}$ for 2 weeks. As resistance of $R$. marinus to aminoglycoside antibiotics had been reported previously (Alfredsson et al., 1988), streptomycin $\left(1.56 \mu \mathrm{g} \mathrm{ml}^{-1}\right)$ was added to the enrichment medium to facilitate growth of Rhodothermus-like species and to prevent overgrowth of fast-growing opportunistlike Bacillus species. Previous experiments showed that Bacillus sp. and R. marinus exhibited different levels of resistance to streptomycin of up to $0.78 \mu \mathrm{g} \mathrm{ml}^{-1}$ and $12.5 \mu \mathrm{g} \mathrm{ml}^{-1}$, respectively (data not shown). Growth was not observed in the dilutions, but was observed after concentrating the cultures and subsequent spreading on agar plates containing marine agar (DSMZ medium 514; Bacto marine broth, Difco 2216) diluted to half strength with water (designated MB1/2) (Marteinsson et al. 1995). Homogeneous colonies appeared on the plates and nine colourless colonies were randomly picked and purified by restreaking on the same medium at least six times. Isolates PRI 2894, PRI 2895, PRI 2896, PRI 2897, PRI 2898, PRI 2901, PRI $2902^{\mathrm{T}}$, PRI 2904 and PRI 2908 were further examined. R. marinus DSM $4252^{\mathrm{T}}$ was used as a reference strain throughout this work.

For phenotypic analysis, the novel isolates were grown on agar medium MB1/2. They showed very similar phenotypic characteristics, which were consistent with their assignment to the genus Rhodothermus. They stained Gramnegative and were positive for catalase and negative for oxidase. Colonies were circular, smooth, viscous and 2$3 \mathrm{~mm}$ in diameter after incubation at $70{ }^{\circ} \mathrm{C}$ for 4 days. Colonies were colourless, whereas those of $R$. marinus $4252^{\mathrm{T}}$ are orange-red (Alfredsson et al., 1988). Sensitivity of the strains to antibiotics was examined at $65{ }^{\circ} \mathrm{C}$ on plates using standard antibiotic discs $(6 \mathrm{~mm})$ from Oxoid. The inhibition zone was measured after $24 \mathrm{~h}$ and strains scored sensitive to an antibiotic if the zone was larger than $20 \mathrm{~mm}$ in diameter (Kristjansson et al., 1994). The strains were sensitive to ampicillin $(10 \mu \mathrm{g})$, chloramphenicol $(30 \mu \mathrm{g})$, erythromycin $(15 \mu \mathrm{g})$, novobiocin $(30 \mu \mathrm{g})$, penicillin $\mathrm{G}$ (10 IU) and rifampicin $(2 \mu \mathrm{g})$. They were resistant to gentamicin $(10 \mu \mathrm{g})$, kanamycin $(30 \mu \mathrm{g})$, nalidixic acid $(30 \mu \mathrm{g})$, polymyxin B (300 IU) and streptomycin $(10 \mu \mathrm{g})$. Phase-contrast microscopy revealed that cells of strain PRI $2902^{\mathrm{T}}$ occurred singly or in short chains during the exponential phase. Motility and endospores were never observed. However, motility has been observed for $R$. marinus DSM $4252^{\mathrm{T}}$. Cell morphology of strain PRI $2902^{\mathrm{T}}$ was examined using a Leo Supra 25 scanning electron microscope. Cells appeared as irregular rods and measured approximately $0.5 \mu \mathrm{m}$ in width and $1.5-3.5 \mu \mathrm{m}$ in length (Supplementary Fig. S1, available in IJSEM Online). The DNA G + C content of strain PRI $2902^{\mathrm{T}}$ was $60.9 \mathrm{~mol} \%$, determined at the DSMZ according to Mesbah et al. (1989). Phenotypically, the novel isolates differed from $R$. marinus $4252^{\mathrm{T}}$ by characteristics represented in Table 1 .

Isolates PRI 2894, PRI 2895, PRI 2898, PRI 2901, PRI $2902^{\mathrm{T}}$, PRI 2904 and PRI 2908 were grown in liquid medium $\mathrm{MB} 1 / 2$ at several temperatures, $\mathrm{pH}$ and $\mathrm{NaCl}$ concentrations. Growth was examined as described previously (Marteinsson et al., 1995). Growth was observed at $55-80{ }^{\circ} \mathrm{C}$, with optimum growth at $70-75{ }^{\circ} \mathrm{C}$. All isolates grew in the presence of $1 \%$ and up to $6 \% \mathrm{NaCl}$. However, a slight difference was observed for the optimal $\mathrm{NaCl}$ concentration which ranged from 1 to $3 \% \mathrm{NaCl}$. Growth occurred between $\mathrm{pH} 6.0$ and 8.0; optimum growth occurred around $\mathrm{pH}$ 7.0. Growth on single carbon sources was tested as described previously (Alfredsson et al., 1985; Marteinsson et al., 1995) on plates containing MB1/2 without peptone and yeast extract. The strains utilized asparagine, aspartate, casein, Casamino acids, gelatin, glutamate, glutamine, pyruvate and starch. Anaerobic growth was examined as described previously (Marteinsson et al., 1995). The isolates could not grow anaerobically and oxygen could not be replaced by nitrate.

Growth of isolates PRI 2895, PRI 2901 and PRI $2902^{\mathrm{T}}$ and R. marinus DSM $4252^{\mathrm{T}}$ was examined under in situ hydrostatic pressure $(25 \mathrm{MPa})$, as well as under atmospheric hydrostatic pressure $(0.1 \mathrm{MPa})$. Experiments were performed in duplicate as described previously (Marteinsson et al., 1999). Growth was monitored by microscopic observation and by measuring the turbidity at $600 \mathrm{~nm}$. All strains exhibited growth at both 0.1 and $25 \mathrm{MPa}$. R. marinus DSM $4252^{\mathrm{T}}$ produced about $30 \%$ fewer cells under hydrostatic pressure of $25 \mathrm{MPa}$. Furthermore, cell deformations were observed, which were never observed at atmospheric pressure. However, the in situ hydrostatic pressure of $25 \mathrm{MPa}$ did not affect the growth rates of isolates PRI 2901 and PRI $2902^{\mathrm{T}}$ and strain PRI 2895 produced about $35 \%$ more cells than at atmospheric hydrostatic pressure. No cell deformations were observed for isolates PRI 2895, PRI 2901 and PRI $2902^{\mathrm{T}}$ when grown under in situ hydrostatic pressure, although the cells appeared shorter.

Fatty acids were extracted from strain PRI $2902^{\mathrm{T}}$ and $R$. marinus DSM $4252^{\mathrm{T}}$ according to the protocol of the MIDI system. Analysis by GC was controlled by the MIS software and the peaks were automatically integrated and identified by the Microbial Identification software package (Sasser, 1990). The general fatty acid profiles were similar to those presented by Silva et al. (2000) for $R$. marinus strains and indicated that PRI $2902^{\mathrm{T}}$ belonged to the genus Rhodothermus. However, the comparison was inadequate as PRI $2902^{\mathrm{T}}$ could not grow in the medium used by Silva et al. (2000). The fatty acid profiles of PRI $2902^{\mathrm{T}}$ and $R$. 
Table 1. Characteristics that distinguish the novel strains from Rhodothermus marinus

Strains: 1, Rhodothermus profundi sp. nov. PRI $2902^{\mathrm{T}}$; 2, R. profundi sp. nov. PRI 2901; 3, R. profundi sp. nov. PRI 2898; 4, R. profundi sp. nov. PRI 2895; 5, R. marinus DSM $4542^{\mathrm{T}}$. Data from this study. ND, Not determined.

\begin{tabular}{|c|c|c|c|c|c|}
\hline Characteristic & 1 & 2 & 3 & 4 & 5 \\
\hline Pigmentation & None & None & None & None & Orange-red \\
\hline Optimum growth temperature $\left({ }^{\circ} \mathrm{C}\right)$ & 70 & 70 & 70 & 75 & 65 \\
\hline Growth at $50{ }^{\circ} \mathrm{C}$ & - & - & - & - & + \\
\hline Maximum growth temperature $\left({ }^{\circ} \mathrm{C}\right)$ & 80 & 80 & 80 & 80 & 77 \\
\hline Growth in $6 \% \mathrm{NaCl}$ & - & - & - & + & + \\
\hline \multicolumn{6}{|l|}{ Resistance to: } \\
\hline Rifampicin & - & - & - & - & + \\
\hline Erythromycin & - & - & - & - & + \\
\hline Motility & - & - & - & - & + \\
\hline DNA G $+C$ content $(\mathrm{mol} \%)$ & 60.9 & ND & $\mathrm{ND}$ & ND & 64.4 \\
\hline \multicolumn{6}{|l|}{ Utilization of: } \\
\hline Acetate & - & - & - & - & + \\
\hline D-Galactose & - & - & - & - & + \\
\hline Sucrose & - & - & - & - & + \\
\hline Maltose & - & - & - & - & + \\
\hline Lactose & - & - & - & - & + \\
\hline Effect of hydrostatic pressure & None & None & None & Positive & Negative \\
\hline
\end{tabular}

marinus DSM $4252^{\mathrm{T}}$ grown in parallel in liquid medium $\mathrm{MB} 1 / 2$ at $70{ }^{\circ} \mathrm{C}$ are given in Table 2 . Both strains contained anteiso- $\mathrm{C}_{15: 0}$, iso- $\mathrm{C}_{16: 0}$, iso- $\mathrm{C}_{17: 0}$ and anteiso- $\mathrm{C}_{17: 0}$ as predominant fatty acids, although in different ratios. The most abundant fatty acid in PRI $2902^{\mathrm{T}}$ was iso- $\mathrm{C}_{17: 0}$, whereas it was iso- $\mathrm{C}_{16: 0}$ in $R$. marinus DSM $4252^{\mathrm{T}}$. Furthermore, the proportion of straight-chain fatty acids was lower in PRI $2902^{\mathrm{T}}$. Quinone and polar lipid analyses were carried out by the Identification service and Dr B. J. Tindall, DSMZ, Braunschweig, Germany. Strain PRI $2902^{\mathrm{T}}$ contained menaquinone MK-7 (100\%), which is the predominant respiratory quinone in $R$. marinus DSM

Table 2. Cellular fatty acid composition (\%) of strain PRI $2902^{\top}$ and $R$. marinus DSM $4252^{\top}$

Data from this study. Cells were cultured in medium MB1/2 at $70{ }^{\circ} \mathrm{C}$. Fatty acids represented by less than $0.5 \%$ were omitted. ND, Not detected.

\begin{tabular}{|c|c|c|}
\hline Fatty acid & PRI $2902^{\mathrm{T}}$ & DSM $4252^{T}$ \\
\hline \multicolumn{3}{|l|}{ Straight-chain } \\
\hline$C_{16: 0}$ & 1.8 & 4.1 \\
\hline $\mathrm{C}_{18: 0}$ & $\mathrm{ND}$ & 0.6 \\
\hline \multicolumn{3}{|l|}{ Branched-chain } \\
\hline iso- $\mathrm{C}_{14: 0}$ & 0.8 & 3.2 \\
\hline iso- $\mathrm{C}_{15: 0}$ & 7.4 & 6.0 \\
\hline anteiso- $\mathrm{C}_{15: 0}$ & 10.0 & 12.3 \\
\hline iso- $\mathrm{C}_{16: 0}$ & 15.8 & 27.8 \\
\hline iso- $\mathrm{C}_{17: 0}$ & 36.9 & 20.7 \\
\hline anteiso- $\mathrm{C}_{17: 0}$ & 18.3 & 13.9 \\
\hline iso- $\mathrm{C}_{18: 0}$ & 7.2 & 8.8 \\
\hline
\end{tabular}

$4252^{\mathrm{T}}$ (97\%) (Tindall, 1991). The polar lipid pattern of PRI $2902^{\mathrm{T}}$ was similar to that of $R$. marinus DSM $4252^{\mathrm{T}}$ (Tindall, 1991) with diphosphatidylglycerol and phosphatidylethanolamine as major phospholipids. Phosphatidylglycerol was also detected, as well as phospholipids PL1-PL2 and glycolipids GL1-GL3. The chemotaxonomic properties of strain PRI $2902^{\mathrm{T}}$ support its affiliation to the genus Rhodothermus.

Genomic DNA was isolated with the Master Pure DNA Purification kit (Epicentre). The 16S rRNA gene was amplified with primers F9 and R1544 as described previously (Skirnisdottir et al., 2000). Nucleotide sequences were determined using an Applied Biosystems 3730 DNA analyser and the BigDye terminator cycle sequencing kit. Primers F9 and R1544 were used for sequencing, as well as primers F338, R357, R805 and R1195 (Skirnisdottir et al., 2000). The almost complete $16 \mathrm{~S}$ rRNA gene sequences (1509 bp), which were determined for all nine isolates, were identical. Comparison of this sequence with sequences available from public databases demonstrated that the isolates belonged to the genus Rhodothermus. The sequence showed $98.1 \%$ similarity to the sequence of $R$. marinus DSM $4252^{\mathrm{T}}$ (X80994), which was the most closely related species. This is below the threshold value of $98.7 \%$ that was recently suggested for species definition (Stackebrandt \& Ebers, 2006). The two sequences were aligned with those of related bacteria using CLUSTAL $\mathrm{X}$ (Thompson et al., 1997). Evolutionary distance matrices were calculated using the Kimura two-parameter model (Kimura, 1980). The 16S rRNA gene sequence of strain PRI $2902^{\mathrm{T}}$ exhibited $85 \%$ similarity to the sequence of the type strain of Salinibacter ruber of the family 'Rhodothermaceae' and $80 \%$ similarity to the type strain of Thermonema 
lapsum (Hudson et al., 1989; Antón et al., 2002; Ludwig et al., 2008). DNA-DNA reassociation between strain PRI $2902^{\mathrm{T}}$ and R. marinus DSM $4252^{\mathrm{T}}$ was performed by the DSMZ, as described by De Ley et al. (1970) with the modifications of Huß et al. (1983); a value of $37.2 \%$ was obtained, which clearly indicated that the isolates described here do not belong to $R$. marinus when a threshold value of $70 \%$ DNA-DNA reassociation is adopted for defining species (Wayne et al., 1987).

Five of the novel isolates (PRI 2894, PRI 2895, PRI 2898, PRI $2902^{\mathrm{T}}$ and PRI 2908) were analysed by amplifiedfragment length polymorphism (AFLP) fingerprinting. Three $R$. marinus reference strains were included: the type strain DSM $4252^{\mathrm{T}}$ from north-west Iceland (Alfredsson et al., 1988) and two colourless isolates, PRI 831 and PRI 1298, from south and north-east Iceland, respectively (Petursdottir et al., 2000). AFLP analysis was performed essentially as described previously (Vos et al., 1995). Genomic DNA was digested with ApaI and TaqI and ligated to double-stranded adapters. Primers A00 and T00 were used for pre-selective amplification and A01-6-FAM and T00 for selective amplification (Huys \& Swings, 1999). The selective amplification products were separated on a $6 \%$ acrylamide gel with $8 \mathrm{M}$ urea. The AFLP fingerprints were visualized using the Typhoon 9400 Variable Mode Imager (Amersham). The presence of individual bands was scored manually. Clustering of the patterns was performed with NTSYSpc (Rohlf, 2008) using the Dice correlation coefficient and the UPGMA clustering algorithm (Fig. 1). Each fingerprint consisted of a mean of $80 \pm 8$ bands where only eight bands were common for all the strains. An identical banding pattern among the novel isolates was observed. However, a considerable genetic heterogeneity was seen between the novel isolates and the three Icelandic R. marinus reference strains (Fig. 1). The former were $26 \%$ similar to R. marinus DSM $4252^{\mathrm{T}}$ and $22 \%$ and $26 \%$ similar to the colourless isolates PRI 831 and PRI 1289, respectively. For some taxonomic groups, AFLP pattern similarity above $60 \%$ indicates different strains of the same species (Savelkoul et al., 1999; Thompson et al. 2004). Thus, the AFLP results presented here further support the species status of the isolates described.

On the basis of 16S rRNA gene phylogeny and chemotaxonomy, it is clear that the isolates described here belong to the genus Rhodothermus. DNA-DNA hybridization supports their status as a novel species. The strains can be differentiated genotypically from $R$. marinus by AFLP as well as phenotypically by their colony colour, fatty acid composition, their optimum and maximum temperatures for growth, response to hydrostatic pressure and sensitivity to rifampicin and erythromycin, as well as their inability to assimilate acetate, galactose, sucrose, maltose and lactose. Therefore, it is concluded that the strains examined in this study represent a novel species within the genus Rhodothermus. Because of the deep origin of the isolates, the name Rhodothermus profundi sp. nov. is proposed with PRI $2902^{\mathrm{T}}\left(=\mathrm{DSM} 22212^{\mathrm{T}}=\mathrm{JCM} 15944^{\mathrm{T}}\right)$ as the type strain.

\section{Description of Rhodothermus profundi sp. nov.}

Rhodothermus profundi (pro.fun'di. L. n. profundum the depths of the sea; L. gen. n. profundi of/from the depths of the sea).

Cells are non-spore-forming, non-motile rods measuring $0.5 \mu \mathrm{m}$ in width and $1.5-3.5 \mu \mathrm{m}$ in length. Aerobic, oxidase-negative, catalase-positive. Cells stain Gram-negative. Colonies are cream, circular, smooth, viscous and 2$3 \mathrm{~mm}$ in diameter after incubation at $70{ }^{\circ} \mathrm{C}$ for 4 days on half-strength marine agar (diluted with water). Thermophilic, grows between 55 and $80{ }^{\circ} \mathrm{C}$, with optimum growth at $70{ }^{\circ} \mathrm{C}$. Neutrophilic, grows between $\mathrm{pH} 6.0$ and 8.0, with optimum growth at $\mathrm{pH}$ 7.0. Minimum and maximum $\mathrm{NaCl}$ concentrations for growth are $1 \%$ and $5 \%$, respectively; optimum growth is at $2-3 \% \mathrm{NaCl}$. Grows in full-strength marine broth and half-strength marine broth (MB1/2), with or without agar. L-Asparagine, L-aspartate, casein, Casamino acids, gelatin, L-glutamate, L-glutamine,
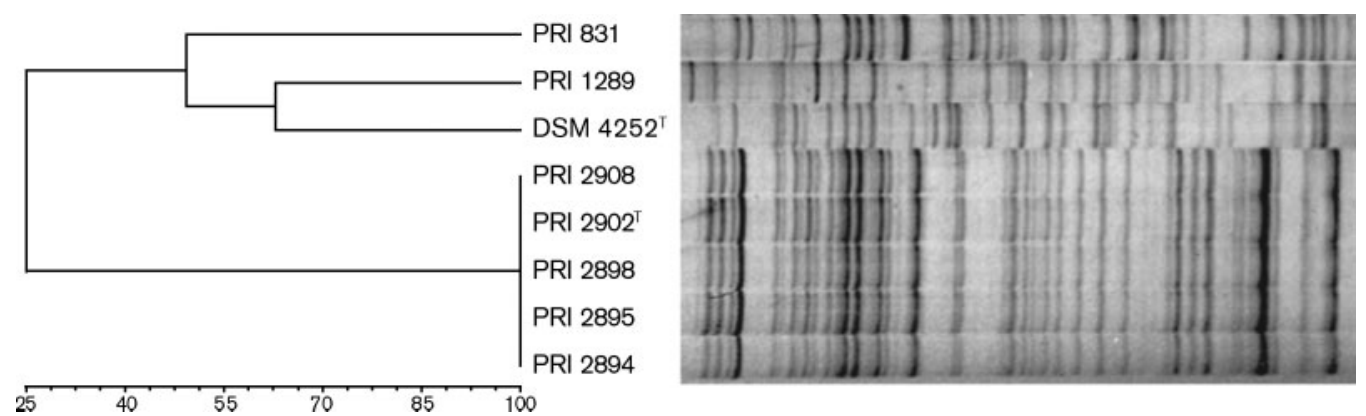

Fig. 1. AFLP profiles (partial) and a corresponding dendrogram for isolates PRI 2894, PRI 2895, PRI 2898, PRI 2902 ${ }^{\top}$ and PRI 2908, and R. marinus DSM $4252^{\top}$. Two colourless $R$. marinus isolates, PRI 831 and PRI 1289, are also included. Cluster analysis was performed using the Dice correlation coefficient and the UPGMA clustering algorithm. The correlation coefficient is expressed as a percentage value. 
pyruvate and starch are used as sole sources of carbon for energy and growth. Does not utilize acetate, L-alanine, adonitol, arabinose, L-arginine, butyrate, citrate, dulcitol, formate, fructose, galactose, gluconate, glucose, lactose, glycerol, L-histidine, inositol, inulin, L-isoleucine, L-leucine, L-lysine, malate, maltose, mannitol, L-phenylalanine, 2-oxoglutarate, L-proline, raffinose, rhamnose, L-serine, sorbitol, sucrose, tartrate, trehalose, L-threonine, L-valine or xylose. Sensitive to ampicillin, chloramphenicol, erythromycin, novobiocin and penicillin G. Resistant to gentamicin, kanamycin, nalidixic acid, polymyxin $\mathrm{B}$ and streptomycin. Contains MK-7. The major fatty acids are iso- $\mathrm{C}_{17: 0}$, anteiso- $\mathrm{C}_{17: 0}$, iso- $\mathrm{C}_{16: 0}$ and anteiso- $\mathrm{C}_{15: 0}$.

The type strain is PRI $2902^{\mathrm{T}}\left(=\mathrm{DSM} 22212^{\mathrm{T}}=\mathrm{JCM}\right.$ $\left.15944^{\mathrm{T}}\right)$, isolated from the hydrothermal vent fields of Genesis $\left(12.449844^{\circ} \mathrm{N} 103.56812^{\circ} \mathrm{W}\right)$ in the Pacific Ocean. The DNA G $+\mathrm{C}$ content of the type strain is $60.9 \mathrm{~mol} \%$.

\section{Acknowledgements}

We thank the chief scientist of the French oceanographic cruise AMISTAD (1999), Christian Jeanthon and the captain and crew of the NO L'Atalante and the DSV Nautile pilots and support crew. We gratefully acknowledge Daniel Prieur for the invitation to the cruise and Sólveig Ólafsdóttir for technical assistance.

\section{References}

Alfredsson, G. A., Baldursson, S. \& Kristjansson, J. K. (1985). Nutritional diversity among Thermus sp. isolated from Icelandic hot springs. Syst Appl Microbiol 6, 308-311.

Alfredsson, G. A., Kristjansson, J. K., Hjorleifsdottir, S. \& Stetter, K. O. (1988). Rhodothermus marinus gen. nov., a thermophilic, halophilic bacterium from submarine hot springs in Iceland. J Gen Microbiol 134, 299-306.

Antón, J., Oren, A., Benlloch, S., Rodriguez-Valera, F., Amann, R. \& Rosselló-Mora, R. (2002). Salinibacter ruber gen. nov., sp. nov., a novel, extremely halophilic member of the Bacteria from saltern crystallizer ponds. Int J Syst Evol Microbiol 52, 485-491.

Bjornsdottir, S. H., Blondal, T., Hreggvidsson, G. O., Eggertsson, G., Petursdottir, S. K., Hjorleifsdottir, S., Thorbjarnardottir, S. H. \& Kristjansson, J. K. (2006). Rhodothermus marinus: physiology and molecular biology. Extremophiles 10, 1-16.

De Ley, J., Cattoir, H. \& Reynaerts, A. (1970). The quantitative measurement of DNA hybridization from renaturation rates. Eur $J$ Biochem 12, 133-142.

Degryse, E., Glansdorff, N. \& Piérard, A. (1978). A comparative analysis of extreme thermophilic bacteria belonging to the genus Thermus. Arch Microbiol 117, 189-196.

Hudson, J. A., Schofield, K. M., Morgan, H. W. \& Daniel, R. M. (1989). Thermonema lapsum gen. nov., sp. nov., a thermophilic gliding bacterium. Int J Syst Bacteriol 39, 485-487.

Huß, V. A. R., Festl, H. \& Schleifer, K. H. (1983). Studies on the spectrophotometric determination of DNA hybridization from renaturation rates. Syst Appl Microbiol 4, 184-192.

Huys, G. \& Swings, J. (1999). Evaluation of a fluorescent amplified fragment length polymorphism (FAFLP) methodology for the genotypic discrimination of Aeromonas taxa. FEMS Microbiol Lett 177, 83-92.
Kimura, M. (1980). A simple method for estimating evolutionary rates of base substitutions through comparative studies of nucleotide sequences. J Mol Evol 16, 111-120.

Kristjansson, J. K., Hjorleifsdottir, S., Marteinsson, V. \& Alfredsson, G. A. (1994). Thermus scotoductus, sp. nov., a pigment-producing thermophilic bacterium from hot tap water in Iceland and including Thermus sp. X-1. Syst Appl Microbiol 17, 44-50.

Ludwig, W., Euzéby, J. \& Whitman, W. B. (2008). Draft taxonomic outline of the Bacteroidetes, Plantomycetes, Chlamydiae, Spirochaetes, Fibrobacteres, Fusobacteria, Acidobacteria, Verrucomicrobia, Dictyoglomi, and Gemmatimonadetes. http://www.bergeys.org/outlines/Bergeys_Vol_ 4_Outline.pdf

Marteinsson, V. T., Birrien, J. L., Kristjansson, J. K. \& Prieur, D. (1995). First isolation of thermophilic aerobic non-sporulating heterotrophic bacteria from deep-sea hydrothermal vents. FEMS Microbiol Ecol 18, 163-174.

Marteinsson, V. T., Birrien, J. L., Jeanthon, C. \& Prieur, D. (1996). Numerical taxonomic study of thermophilic Bacillus isolated from three geographically separated deep-sea hydrothermal vents. FEMS Microbiol Ecol 21, 255-266.

Marteinsson, V. T., Birrien, J. L., Raguenes, G., da Costa, M. \& Prieur, D. (1999). Isolation and characterization of Thermus thermophilus Gy1211 from a deep-sea hydrothermal vent. Extremophiles 3, 247-251.

Mesbah, M., Premachandran, U. \& Whitman, W. B. (1989). Precise measurement of the $\mathrm{G}+\mathrm{C}$ content of deoxyribonucleic acid by highperformance liquid chromatography. Int J Syst Bacteriol 39, 159167.

Moreira, L., Nobre, M. F., Sa Correira, I. \& da Costa, M. S. (1996). Genomic typing and fatty acid composition of Rhodothermus marinus. Syst Appl Microbiol 19, 83-90.

Petursdottir, S. K., Hreggvidsson, G. O., da Costa, M. S. \& Kristjansson, J. K. (2000). Genetic diversity analysis of Rhodothermus reflects geographical origin of the isolates. Extremophiles 4, 267274.

Rohlf, F. J. (2008). NTSYSpc: numerical taxonomy system, v2.20. Setauket, NY: Exeter Publishing Ltd.

Sasser, M. (1990). Identification of bacteria by gas chromatography of cellular fatty acids, MIDI Technical Note 101. Newark, DE: MIDI Inc.

Savelkoul, P. H. M., Aarts, H. J. M., de Haas, J., Dijkshoorn, L., Duim, B., Otsen, M., Rademaker, J. L. W., Schouls, L. \& Lenstra, J. A. (1999). Amplified-fragment length polymorphism analysis: the state of an art. J Clin Microbiol 37, 3083-3091.

Silva, Z., Horta, C., da Costa, M. S., Chung, A. P. \& Rainey, F. A. (2000). Polyphasic evidence for the reclassification of Rhodothermus obamensis Sako et al. 1996 as a member of the species Rhodothermus marinus Alfredsson et al. 1988. Int J Syst Evol Microbiol 50, 14571461.

Skirnisdottir, S., Hreggvidsson, G. O., Hjorleifsdottir, S., Marteinsson, V. T., Petursdottir, S., Holst, O. \& Kristjansson, J. K. (2000). Influence of sulfide and temperature on species composition and community structure of hot spring microbial mats. Appl Environ Microbiol 66, 2835-2841.

Stackebrandt, E. \& Ebers, J. (2006). Taxonomic parameters revisited: tarnished gold standards. Microbiol Today 33, 152-155.

Thompson, J. D., Gibson, T. J., Plewniak, F., Jeanmougin, F. \& Higgins, D. G. (1997). The CLUSTAL_X windows interface: flexible strategies for multiple sequence alignment aided by quality analysis tools. Nucleic Acids Res 25, 4876-4882.

Thompson, F. L., lida, T. \& Swings, J. (2004). Biodiversity of vibrios. Microbiol Mol Biol Rev 68, 403-431. 
Tindall, B. J. (1991). Lipid composition of Rhodothermus marinus. FEMS Microbiol Lett 80, 65-68.

Vos, P., Hogers, R., Bleeker, M., Reijans, M., van de Lee, T., Hornes, M., Frijters, A., Pot, J., Peleman, J. \& other authors (1995). AFLP: a new technique for DNA fingerprinting. Nucleic Acids Res 23, 4407-4414.
Wayne, L. G., Brenner, D. J., Colwell, R. R., Grimont, P. A. D., Kandler, O., Krichevsky, M. I., Moore, L. H., Moore, W. E. C., Murray, R. G. E. \& other authors (1987). International Committee on Systematic Bacteriology. Report of the ad hoc committee on reconciliation of approaches to bacterial systematics. Int J Syst Bacteriol 37, 463-464. 